DOI: $10.33067 /$ SE.4.2021.4

Agata Domachowska

\title{
The Status of the European Integration Process of the Western Balkan Countries
}

\begin{abstract}
For many years, the priority of foreign policy determined by subsequent governments of the six Western Balkan countries, i.e., Albania, Bosnia and Herzegovina, Kosovo, Montenegro, North Macedonia, and Serbia has been their accession to the European Union. Yet, in recent years, this process has slowed down, and so it can be assumed that in the coming years there will be no further enlargement of the EU to include any of the Western Balkan countries. The following article is aimed at analysing the present status of European integration with regard to the aforementioned states, and discusses the causes of regression in this process which can be identified on the side of the non-EU Western Balkan states and the European Union itself. Their integration is also a key issue in the context of the increasingly stronger presence of non-EU players such as China, Russia, and Turkey, all competing with the European Union for influence in this important region. The study was based on discourse analysis (including the critical discourse analysis approach) and content analysis.
\end{abstract}

Keywords: Western Balkans, European Union, Enlargement, China, Pandemic, COVID-19

\section{The Western Balkans' EU Integration}

The Western Balkan countries (currently these include Albania, Bosnia and Herzegovina, Kosovo, Montenegro, North Macedonia, and Serbia ${ }^{1}$ ) have been seeking to join the European Union for years as it has been a priority of foreign policy identified by subsequent governments of these

^ Agata Domachowska - Nicolaus Copernicus University in Torun and The Institute of Central Europe in Lublin, e-mail: a.domachowska@umk.pl, ORCID: 00000002-8521-9399.

1 The list omits Croatia as it has been an EU member since 1st July 2013. 
states. In March 2004, Macedonia ${ }^{2}$ was the first of the six aforementioned Western Balkan coun tries to apply for the status of an EU candidate country, receiving this status in 2005. Montenegro followed suit in 2008, obtaining the status of a candidate country two years later in 2010. Serbia submitted a similar application in 2009, and was granted the status in 2012. Albania also applied for membership in 2009, even earlier than Serbia (Albania in April and Serbia in December) and was eventually granted the status of a candidate country in June 2014.

On the other hand, Kosovo and Bosnia and Herzegovina are the two states among the Western Balkan countries which remain only potential candidates. The problem with the future of Kosovo's European integration is directly related to the normalisation of its relations with Serbia. At the same time, it should be remembered that there is still no unanimity among the Member States regarding the Kosovo's statehood, which is not recognised by Cyprus, Greece, Romania, Slovakia, nor Spain. In turn, Bosnia and Herzegovina is struggling with internal problems, political disputes, and the lack of reforms (in such areas as the rule of law, democracy, public administration, and fundamental rights), which hinders its chances of joining the European Union as the European Commission has set 14 key priorities to be fully implemented by the country in view of starting EU accession negotiations. ${ }^{3}$

Of the six Western Balkan countries, Montenegro and Serbia remain the most advanced in the EU integration process. Montenegro began accession negotiations in 2012 and has so far opened 33 chapters, but only three of them have been provisionally closed. Such a slow pace of negotiations is also characteristic of Serbia's integration process, which started in 2014, but only 18 out of 35 chapters have been opened and only two have been provisionally closed. ${ }^{4}$

After many years of effort, and as a result of a finally resolved dispute with Greece, ${ }^{5}$ North Macedonia also managed to gain the EU's consent to start negotiations in 2020. However, as of the time of this writing (October 2021), not even the first intergovernmental conference, which would formally initiate the negotiations, has been convened. The same is also true

2 Since February 2019, the official name of the country is North Macedonia.

3 B. Stanicek, Bośnia i Hercegowina: trudna droga do cztonkostwa w UE, Biuro Analiz Parlamentu Europejskiego, czerwiec 2021, pp. 1-2.

4 The European Parliament, The Western Balkans, 2021, https:/www.europarl.europa.eu/factsheets/en/sheet/168/the-western-balkans (access 29.09.2021).

5 K. Pawłowski, "Dtuga Droga": Macedonia Pótnocna cztonkiem NATO, "Komentarze IEŚ, no. 172, 17.04.2020, https://ies.lublin.pl/komentarze/dluga-droga-macedonia-polnocna-czlonkiem-nato/ (access 8.10.2021). 
of Albania; together with North Macedonia, it has finally been given the green light to begin negotiations, but in practice has not yet started them either. From the perspective of the integration process, both countries receive equal treatment from the EU, i.e., decisions regarding the further pace of integration concern both Albania and North Macedonia. However, there have been voices that advocate treating these countries in a separate fashion, as suggested by, for example, Commissioner for Neighbourhood and Enlargement Oliver Varhelyi; however, this has been met with open criticism expressed by some Member States, particularly Germany. ${ }^{6}$

The EU integration process of North Macedonia and Albania is currently being blocked by Bulgaria, which does not consent to the holding of the first intergovernmental conference. In December 2020, the Bulgarian authorities did not agree to the European Commission's proposal ${ }^{7}$ regarding the negotiating framework with these two Balkan countries, arguing that the Macedonian side is not implementing the provisions adopted in the 2017 Treaty of Friendship, Good-neighbourliness, and Cooperation Between the Republic of Macedonia and the Republic of Bulgaria (Macedonian: Договор за пријателство, добрососедство и соработка меѓу Република Македонија и Република Бугарија). The dispute is complex and touches on events and historical figures that both countries claim rights to. Bulgaria directly accuses North Macedonia of appropriating Bulgarian history. Moreover, in the EU accession process, Bulgaria demands that the term "the Macedonian language" be abandoned and replaced with "the official language of the candidate country". ${ }^{8}$ Other EU countries strongly support the initiation of accession negotiations with North Macedonia, stating explicitly that the authorities in Skopje have already met all the criteria which enables them to organise an intergovernmental conference, and, at the same time, some EU members criticise Bulgaria for blocking the integration process of its neighbour, solely for historical or cultural reasons. Moreover, as emphasised by Nikola Dimitrov, the Minister of Foreign Affairs of North Macedonia, the issue of language and identity should not be an obstacle on the way to the fulfilment of any country's aspirations to become a member of the EU. In accordance

${ }^{6}$ J. Barigazzi, EU commissioner floats shift on Albania membership talks, "Politico", 7.05.2021, https://www.politico.eu/article/eu-commission-albania-membership/ (access 2.10.2021).

7 M. Szpala, M. Seroka, Butgarska blokada negocjacji akcesyjnych z Macedonia Pótnocna, „Analizy OSW”, 14.12.2020, https://www.osw.waw.pl/pl/publikacje/ analizy/2020-12-14/bulgarska-blokada-negocjacji-akcesyjnych-z-macedonia-polnocna (access 2.10.2021).

8 Ibidem. 
with the provisions of the Lisbon Treaty, European states should respect cultural and linguistic diversity. ${ }^{9}$ It is hard to expect, however, that this dispute will soon be resolved - certainly not until a new government is formed in Bulgaria. ${ }^{10}$

Table 1. The status of the European integration process of the Western Balkan countries (October 2021)

\begin{tabular}{|l|c|c|c|c|}
\hline & $\begin{array}{c}\text { The Stabilisa- } \\
\text { tion and } \\
\text { Association } \\
\text { Agreement (en- } \\
\text { try into force) }\end{array}$ & $\begin{array}{c}\text { Application for } \\
\text { EU } \\
\text { Membership }\end{array}$ & $\begin{array}{c}\text { EU candi- } \\
\text { date country } \\
\text { status grant- } \\
\text { ed }\end{array}$ & $\begin{array}{c}\text { Opening of } \\
\text { accession } \\
\text { negotiations }\end{array}$ \\
\hline Albania & 2009 & 2009 & 2014 & $2020^{1}$ \\
\hline $\begin{array}{l}\text { Bosnia } \\
\text { and Herze- } \\
\text { govina }\end{array}$ & 2015 & 2016 & & \\
\hline $\begin{array}{l}\text { Montene- } \\
\text { gro }\end{array}$ & 2010 & 2008 & 2010 & 2012 \\
\hline Kosovo & 2016 & 2004 & 2005 & $2020^{2}$ \\
\hline $\begin{array}{l}\text { North } \\
\text { Macedonia }\end{array}$ & 2004 & 2009 & 2012 & 2014 \\
\hline Serbia & 2013 & & & \\
\hline
\end{tabular}

1 In practice, accession negotiations will be initiated at the first intergovernmental conference. This has not yet taken place due to Bulgaria's veto.

2 In practice, accession negotiations will be initiated at the first intergovernmental conference. This has not yet taken place due to Bulgaria's veto.

Source: Author's own work.

When analysing the issues of the negotiation process of individual Western Balkan countries, it should be noted that the enlargement methodology has been revised in the meantime. The new rules require that the enlargement process is, first and foremost, more credible, predictable, and dynamic. Moreover, the negotiating chapters so far have been divided into six thematic clusters, namely: 1 . fundamental reforms, 2 . the

9 Euronews.Albania, Bulgaria and North Macedonia clash, overshadowing the European perspective of the Westen Balkans once again, 01.10.2021, https://euronews.al/en/ north-macedonia/2021/10/01/bulgaria-and-north-macedonia-clash-overshadowingthe-european-perspective-of-the-westen-balkans-once-again/ (access 5.10.2021).

10 The European Commission, 2021 Enlargement package: European Commission assesses and sets out reform priorities for the Western Balkans and Turkey, 19.10.2021, https://ec.europa.eu/commission/presscorner/detail/en/IP_21_5275 (access 23.10.2021); On 14 November 2021, the third consecutive parliamentary election will be held in Bulgaria. The first one took place in April, followed by the second one in July. On the same day, the Bulgarians will also vote to elect the new president of the country. 
internal market, 3. competitiveness and inclusive growth, 4. green agenda and sustainable connectivity, 5. resources, agriculture, and cohesion, and 6. external relations. ${ }^{11}$ However, what is to be opened first are negotiations on the rule of law, democratic institutions, public administration, and the economy. The proposed changes apply to candidate countries that have not yet started negotiations, namely North Macedonia and Albania. For Montenegro and Serbia, the revised rules will be optional, yet they have decided to continue negotiations under the new methodology.

\section{The Balkan Countries' Troubles on Their Road to EU Membership}

It is beyond any doubt that each of the Balkan countries struggle with numerous problems related to building systems of the rule of law which, for years, has been indicated by annual reports by, inter alia, the American non-governmental organisation Freedom House. In their latest report ("Nations in Transit" 2021), all the six countries are referred to as having a "Transitional Government or Hybrid Regime". On a scale of 1 to 7 (where 1 represents the highest democratisation rate, with 7 being the lowest), Serbia scored 3.89 points (a drop from 3.96), followed by Montenegro 3.82 (a drop from 3.86). Albania also recorded a decrease - from 3.82 to 3.75 and Kosovo - from 3.18 to 3.14. In turn, Bosnia and Herzegovina recorded a slight increase - from 3.32 to 3.36 and North Macedonia - from 3.75 to $3.82 . .^{12}$ These figures mean that in four of the Western Balkan countries, the democratisation process has regressed.

Another critical issue is the problem of corruption, often referred to by the citizens of the Western Balkans as one of the key challenges. Namely, in a Eurobarometer survey (2021), 26\% of the respondents believe that corruption is the greatest problem in the region. Compared to 2015, this result has increased by 11 percentage points $(15 \%) .{ }^{13}$ What is more, as

11 A. Domachowska, Nowe zasady rozszerzenia Unii Europejskiej i reakcje państw Batkanów Zachodnich, "Komentarze IEŚ 118”, 14.02.2020, https://ies.lublin.pl/komentarze/nowe-zasady-rozszerzenia-unii-europejskiej-i-reakcje-panstw-balkanowzachodnich/ (access 28.09.2021).

12 Freedom House, Nations in Transit 2021, The Antidemocratic Turn, 2021, p. 24, https://freedomhouse.org/sites/default/files/2021-04/NIT_2021_final_042321.pdf (access 20.09.2021).

${ }^{13}$ In turn, $49 \%$ of respondents considered unemployment as the greatest problem, $46 \%$ - the economic situation, $16 \%$ - crime, and 13\% - brain drain and emigration, Regional Cooperation Council, Balkan Barometer 2021. Infographics. Pocket Edition, 2021, p. 6, https://www.rcc.int/download/docs/Balkan_Barometer_pocket_web.pdf/ d885791a77366a17791270b95a162c16.pdf (access 10.09.2021). 
many as $78 \%$ of the respondents recognised political parties as the most corrupt, $76 \%$ recognised the judiciary as most corrupt, $75 \%$ - customs, $74 \%$ - healthcare provides, and $71 \%$ - the parliament. ${ }^{14}$ The problem of corruption in the Western Balkans is also highlighted by the Transparency International Corruption Perceptions Index, published by Transparency International. When analysing the latest results from 2020 and comparing them with the results from 2019, it becomes evident that the numbers for Montenegro, North Macedonia, and Kosovo are stagnant, while Serbia and Bosnia and Herzegovina have regressed, and only in Albania has the situation improved slightly. Among the Western Balkan countries, Serbia is ranked highest (94), followed by Kosovo and Albania (104), while North Macedonia and Bosnia and Herzegovina (111) are tied in last place. ${ }^{15}$ It is also worth noting that this is North Macedonia's worst result since 2001.

Table 2. Freedom House, Nations in Transit, The Democracy score (20152021)

\begin{tabular}{|l|c|c|c|c|c|c|c|}
\hline & 2015 & 2016 & 2017 & 2018 & 2019 & 2020 & 2021 \\
\hline Albania & 3.86 & 3.86 & 3.86 & 3.89 & 3.89 & 3.89 & 3.75 \\
\hline Bosnia and Herzegovina & 3.54 & 3.50 & 3.46 & 3.36 & 3.32 & 3.32 & 3.36 \\
\hline Kosovo & 2.86 & 2.93 & 3.04 & 3.07 & 3.11 & 3.18 & 3.14 \\
\hline North Macedonia & 3.93 & 3.71 & 3.57 & 3.64 & 3.68 & 3.75 & 3.82 \\
\hline Serbia & 4.32 & 4.25 & 4.18 & 4.04 & 4.00 & 3.96 & 3.89 \\
\hline
\end{tabular}

Source: Author's own work based on annual reports by Freedom House.

Table 3. Transparency International, Corruption Perceptions Index (20142020) $)^{16}$

\begin{tabular}{|l|c|c|c|c|c|c|c|}
\hline & 2014 & 2015 & 2016 & 2017 & 2018 & 2019 & 2020 \\
\hline Albania & 33 & 36 & 39 & 38 & 36 & 35 & 36 \\
\hline Bosnia and Herzegovina & 39 & 38 & 39 & 38 & 38 & 36 & 35 \\
\hline Kosovo & 33 & 33 & 36 & 39 & 37 & 36 & 36 \\
\hline North Macedonia & 45 & 42 & 37 & 35 & 37 & 35 & 35 \\
\hline Serbia & 41 & 40 & 42 & 41 & 39 & 39 & 38 \\
\hline
\end{tabular}

Source: Author's own work based on annual reports by Transparency International, Corruption Perceptions Index.

${ }^{14}$ Regional Cooperation Council, Balkan Barometer 2021. Infographics. Pocket Edition, 2021, p. 90, https://www.rcc.int/download/docs/Balkan_Barometer_pocket_web. pdf/d885791a77366a17791270b95a162c16.pdf (access 10.09.2021).

15 N. Cuckić, Transparency International: Corruption is on the rise in the Western Balkans, 4.02.2021, https://europeanwesternbalkans.com/2021/02/04/transparency-international-corruption-is-on-the-rise-in-the-western-balkans/ (access 10.09.2021).

16 The Corruption Perceptions Index operates on a scale from 0 to 100. 
The same issues are emphasised by the European Commission in its latest report on the Western Balkan countries' EU integration, which states that there has been no significant forward movement in this process. In Montenegro's case, the Commission stresses the need for reforms, particularly with regard to Chapters 23 and 24, and pointed to corruption and organised crime as ongoing problems. The ongoing political crisis in this particular Balkan country is yet another issue raised by the Commission - there is no dialogue between the government and the opposition, while the dispute within the parliamentary majority continues. ${ }^{17}$ In the Commission's opinion, Serbia should intensify its dialogue with Kosovo on the normalisation of bilateral relations. Similarly to Montenegro, it needs to accelerate the implementation of reforms in the areas of judicial independence, combating corruption and organised crime, and strengthening media freedom. At the same time, the EC noticed Serbia's progress within clusters 3 (competitiveness and inclusive growth) and 4 (green agenda and sustainable connectivity) and thus suggested their opening as the Serbian government had met a number of important criteria in this regard. When assessing the progress made by Albania and North Macedonia in their European integration process, the Commission ingeminated the fact that both countries had met all the necessary conditions to start accession negotiations, and thus it was deemed necessary for Bulgaria and North Macedonia to resolve the dispute between them. On the other hand, in the case of Bosnia and Herzegovina, no significant progress has been noted. What remains a problem is the deep polarisation of the Bosnian political scene, which has a negative impact on the pace of implementing changes under the aforementioned 14 priorities. Regarding Kosovo, the EC restated that the country, already in 2018, had satisfied the EU's requirements for visa liberalisation. As in the case of Serbia, it was noted that Kosovo should engage in constructive dialogue with the Serbian side. ${ }^{18}$

\section{A Lack of Strategic EU Engagement in the Region?}

There has been a long period of stagnation in the accession process of the Western Balkan countries, as the last enlargement took place in 2013, when Croatia joined the EU. Currently, it seems that no signifi-

17 Since June 2021, the Democratic Front, the largest grouping that forms the parliamentary majority, has been boycotting the work of the parliament.

18 The European Commission, 2021 Enlargement package: European Commission assesses and sets out reform priorities for the Western Balkans and Turkey, 19.10.2021, https://ec.europa.eu/commission/presscorner/detail/en/IP_21_5275 (access 23.10.2021). 
cant changes will happen in the coming years. However, as late as 2018, the then President of the European Commission, Jean-Claude Juncker, maintained that the year 2025 was a possible date for the accession of all Western Balkan countries to the EU, and not only those which were at the time the most advanced in the accession process (i.e., Montenegro and Serbia $)^{19}$ - yet at present, this date should be considered rather unrealistic. In actuality, no date appears feasible today. However, setting another specific date for the potential accession of the Western Balkan countries to the EU will no longer generate significant enthusiasm in the region, so it seems imperative for the EU to design a fixed integration schedule.

Even the residents of the region no longer seem to believe in such an optimistic scenario, as demonstrated by the latest Eurobarometer surveys. When answering the question "When do you expect the accession of your economy to the EU to happen?", as many as $32 \%$ of the respondents from Serbia and Bosnia and Herzegovina, followed by $31 \%$ from North Macedonia demonstrated their belief that this will never happen. In turn, $39 \%$ of the respondents from Albania say that it will have taken place by 2025 , and $40 \%$ - by 2030 . Kosovo citizens also express optimism regarding this issue; $30 \%$ expect to join the EU by 2025 , and $48 \%$ by $2030 .{ }^{20}$ The insufficient commitment of the EU to the accession process affects the opinions of the people of the Western Balkans about the European Union itself. Namely, compared to 2018 (when it stood at 56\%), support for EU membership has slightly increased (62\% in 2021); however, for instance in Bosnia and Herzegovina, only $42 \%$ of the respondents regarded EU membership as a good thing (39\% opining that it is neither good nor bad), and in Serbia it stands at $50 \%$. On the other hand, as many as $91 \%$ of the respondents in Montenegro and $84 \%$ in Albania perceived accession to the EU as a good thing. ${ }^{21}$

This disenchantment stems from, inter alia, a certain conservativeness of the EU in making decisions about the enlargement process. After resolving the long-running dispute with Greece, and changing the name of the country in 2019, North Macedonia was convinced that it would finally receive the EU's consent to start accession negotiations. However, this

19 G. Gotev, Funcker tells Balkan states 2025 entry possible for all, 26.02.2018, https:// www.euractiv.com/section/enlargement/news/juncker-tells-balkan-states-2025-entrypossible-for-all/ (access 2.10.2021).

20 Regional Cooperation Council, Balkan Barometer 2021. Public opinion. Analytical report, 2021, p. 44, https://www.rcc.int/download/docs/Balkan_Barometer_Public_opinon_2021v4_compressed.pdf/fd1f51228c1d9c4f093617da56304048.pdf (äass 28.09.2021).

${ }^{21}$ Ibidem. 
did not happen right away. At a summit in October 2019, EU leaders did not agree to unblock talks with Macedonia - mainly due to the reluctant stance on enlargement presented by France, the Netherlands, and Denmark..$^{22}$

The talks were reopened only at the following summit in March 2020. This tardiness of the EU caused shock and chagrin among all Western Balkan countries, which began to wonder whether their strife to implement reforms and the fulfilment of the EU's conditions would ultimately lead to membership. ${ }^{23}$ The time wasted by Macedonia on their struggle to become part of the EU was vividly depicted at the Autumn Session of the Parliamentary Assembly of the Council of Europe (PACE) by North Macedonian Deputy Prime Minister for European Affairs Nikola Dimitrov, who, on 30th September 2021 at the start of his speech, remained silent for 16 seconds to reflect the 16 years lost by Macedonia as a candidate for EU membership. ${ }^{24}$ The credibility of the EU is also undermined by the lack of decisions on visa liberalisation for Kosovo citizens, although, already in 2018, the European Commission confirmed that the country had met all the required criteria. ${ }^{25}$

The recent EU-Western Balkans summit, held in Slovenia on 6th October $2021,{ }^{26}$ was to send a signal to the countries of the region that the European Union is still committed to the integration process. The adopted declaration reaffirmed support for the European integration of the Western Balkans, and a commitment to strengthen cooperation in the areas of security and politics, as well as pledging assistance in matters regarding connectivity and green and digital transitions in the

${ }^{22}$ H. von der Burchard, J. Barigazzi, A. Gray, Brussels puts French accent on EU enlargement, "Politico", 4.02.2020, https://www.politico.eu/article/brussels-tries-togive-eu-european-union-enlargement-a-french-accent-north-macedonia-albania-emmanuel-macron-angela-merkel/ (access 26.09.2021).

23 See more: S. Latal, et al., Western Balkans Awaits EU Summit as Membership Hopes Falter, "Balkan insight”, 6.10.2021, https://balkaninsight.com/2021/10/06/western-balkans-awaits-eu-summit-as-membership-hopes-falter/ (access 18.10.2021).

${ }^{24}$ Parliamentary Assembly, North Macedonia's accession to the EU: 'It is high time to move forward', says Nikola Dimitrov, 30.09.2021, https://pace.coe.int/en/news/8458/ north-macedonia-s-accession-to-the-eu-it-is-high-time-to-move-forward-says-nikola-dimitrov (access 5.10.2021).

25 Komisja Europejska, Liberalizacja przepisów wizowych: Komisja potwierdza, że Kosowo spetnia wszystkie wymagane kryteria, 18.07.2018, https:/ec.europa.eu/commission/presscorner/detail/pl/IP_18_4562 (access 21.09.2021).

${ }_{26}$ Previous EU-Western Balkans summits were held on 6th May 2020 in Zagreb (via video conference due to the COVID-19 pandemic) and on 17th May 2018 in Sofia. 
region. ${ }^{27}$ The EU adopted the Economic and Investment Plan for the Western Balkans with a substantial investment package of around 30 billion euros (including 9 billion euros for subsidies and 20 billion euros for investments), which will be launched over the next seven years. The aim of this plan is socio-economic recovery and competitiveness, the support of ecological and digital transformation, and strengthening convergence with the EU, also with the EU's climate goals. ${ }^{28}$ Yet, membership commitments were made at the summit. ${ }^{29}$

The Western Balkans' potential membership also has strategic importance for the EU as one of the world's main international actors. This was recognised during a recent EU-Western Balkans summit by the President of the European Council, Charles Michel, and the President of the European Commission, Ursula von der Leyen, who clearly said that the lack of success in opening negotiations with North Macedonia and Albania is "(...) jeopardising [their] standing and leverage in the region".$^{30}$ The COVID-19 pandemic has clearly revealed (although it has been visible for a long time) the growing influence of other major players in the region, mainly China, Russia, Turkey, and the Arab states, all of which are seeking to compete with the EU. However, Turkey's and Russia's presence in the Balkans is nothing new; these countries have been involved in the region for centuries. In such circumstances, China's appearance should become a strong impulse for the EU to strengthen its position in the region.

China is progressively striving to strengthen its presence in the region through the Belt and Road initiative and the intensification of its cooperation with Albania, Montenegro, Serbia, Bosnia and Herzegovina, and North Macedonia within the $17+1$ format. As Marta Szpala correctly observes, cooperation with China is attractive for the Western Balkan countries as they have limited possibilities of raising capital for large investments. China's engagement has also been a lot less bureaucratic than that

27 European Council, EU-Western Balkans summit, Brdo pri Kranju, Slovenia, 6 October 2021, https://www.consilium.europa.eu/en/meetings/internationalsummit/2021/10/06/ (access 18.10.2021).

28 Brdo Declaration, 6 October 2021, https://www.consilium.europa.eu/ media/52280/brdo-declaration-6-october-2021-en.pdf (access 18.10.2021).

${ }^{29}$ S. Siebold, I. Sekularac, R. Emmott, EU restates Balkan membership guarantee but won't say for when, 6.10.2021, https://www.reuters.com/world/europe/despitefrench-push-eu-leaders-divided-over-common-defence-strategy-2021-10-06/ (access 18.10.2021).

${ }^{30}$ Euronews, EU commits $€ 9$ billion to Western Balkans but political divisions over enlargement persist, 6.10.2021, https://www.euronews.com/2021/10/06/eu-commits-9-billion-towestern-balkans-but-political-divisions-over-enlargement-persist (access 18.10.2021). 
connected to the aid from Western institutions. Moreover, Chinese funds have allowed local elites to help the companies of their supporters. ${ }^{31}$

Therefore, strengthening relations with Beijing is especially fruitful for the leaders of the Balkan countries who, without much effort, can receive loans from China for diverse investments which they can then pride themselves on during election campaigns, thereby strengthening their electorate base. However, there is a danger that most of the Chinese funds are various loans that will eventually have to be paid back by the Balkan countries. In this context, the example of Montenegro should be a warning sign to other countries in the region which may also fall into a debt trap because, in 2014, around 944 million dollars were borrowed by the Montenegrin government from China in order to construct a motorway. ${ }^{32}$ Yet when instalments had to be paid, the Montenegrin government was forced to turn to the European Union for help. Lowering the debt for the construction of part of the motorway was possible due to monetary aid provided by French and American banks..$^{33}$ Additionally, Chinese investments in the region receive increased criticism for their negative impact on the natural environment and air quality. ${ }^{34}$

Despite the growing presence of China in the region, it should be recognised that the EU remains the main export and import partner of the Western Balkan countries. ${ }^{35}$ In 2020, “(...) manufactured goods made up $77 \%$ of EU exports to and $80 \%$ of EU imports from the Western Balkans". ${ }^{36}$

${ }^{31}$ K. Wysocka, Chiny sięgaja po Batkany Zachodnie. Unia Europejska powinna się niepokoic?, „EUROACTIVE.pl”, 11.04.2021, https://www.euractiv.pl/section/polityka-zagraniczna-ue/news/chiny-balkany-ue-unia-europejska-serbia-czarnogora-kosowo-albania-wspolpraca-polityka-zagraniczna-pekin-ekspansja-chinczycy/ (access 18.10.2021).

${ }^{32}$ See: N. Đorđević, Montenegro narrowly avoids Chinese debt trap, for now, 9.08.2021, https://emerging-europe.com/news/montenegro-narrowly-avoids-chinese-debt-trapfor-now/ (access 19.10.2021).

33 S. Janković, Proi korak za izlazak Crne Gore iz duga prema Kini, „Radio Slobodna Evropa”, 9.07.2021, https://www.slobodnaevropa.org/a/crna-gora-kina-kredit$\mathrm{dug} / 31350750 . \mathrm{html}$ (access 19.10.2021).

${ }_{34}$ S. Shehadi, How China is enabling an environmental crisis in the Balkans, "Investment Monitor", 29.01.2021, https://www.investmentmonitor.ai/business-activities/ extractive-industries/how-china-is-enabling-an-environmental-crisis-in-the-balkans (access 12.10.2021).

35 Ch. Schweng, The EU must keep its word to the Western Balkans on the prospect of EU membership, says EESC President, 05.10.2021, https://www.theparliamentmagazine.eu/news/article/the-eu-must-keep-its-word-to-the-western-balkans-on-the-prospect-of-eu-membership-says-eesc-president (access 19.10.2021).

${ }^{36}$ Eurostat, Western Balkans-EU - international trade in goods statistics, https:// ec.europa.eu/eurostat/statistics-explained/index.php?title=Western_Balkans-EU_international_trade_in_goods_statistics\&oldid=526493 (access 19.10.2021). 
During the COVID-19 pandemic, the EU has aimed to support the Balkans, but Russian and Chinese aid for the region has been more spectacular in terms of its public reception. Balkan leaders have repeatedly criticised EU support as tardy, and claimed that the EU lacked solidarity with the countries of the region. ${ }^{37}$ In this context, the gesture of Serbian President Aleksander Vučić, who kissed the Chinese flag as an expression of gratitude for the help (in the form of masks and medical equipment) provided by China in the fight against the COVID-19 pandemic, should be regarded as extremely symbolic. ${ }^{38}$ However, the actual dimension of EU support to the Western Balkan countries during the pandemic should not be forgotten. The total amount of health and socio-economic aid totals 3.3 billion euros. Additionally, the EU has delivered (through various channels) 2.9 million doses of vaccines, and further shipments are planned. ${ }^{39}$

\section{Conclusions}

The analysis of the present status of the integration process in the Western Balkan countries reveals that it requires substantial acceleration and deeper involvement of both sides. Undoubtedly, the Western Balkans still have a long way to be granted membership as this requires the leaders of the region's states to introduce the necessary reforms, especially since the subsequent reports of the European Commission indicate stagnation in this area.

To accelerate the Western Balkans' EU accession, the European Union should demonstrate and prove its involvement in the enlargement process through the preparation of a specific plan and schedule for integration. It is fundamental to outline a detailed timetable for the implementation of reforms by the countries of the Western Balkans, and not to set

37 A.E. Juncos, Vaccine Geopolitics and the EU's Ailing Credibility in the Western Balkans, Carnegie Europe”, 08.07.2021, https://carnegieeurope.eu/2021/07/08/vaccine-geopolitics-and-eu-s-ailing-credibility-in-western-balkans-pub-84900 (access 19.10.2021); A. Ivović, Perception of EU aid amidst the pandemic faces challenges across the Western Balkans, "European Western Balkans", 17.04.2020, https://europeanwesternbalkans.com/2020/04/17/perception-of-eu-aid-amidst-the-pandemic-faces-challenges-across-the-western-balkans/ (access 19.10.2021); J. Simić, Serbia turns to China due to 'lack of EU solidarity' on coronavirus, "EUROACTIVE.com", 18.03.2020, https:// www.euractiv.com/section/china/news/serbia-turns-to-china-due-to-lack-of-eu-solidarity-on-coronavirus/ (access 19.10.2021).

${ }_{38}$ Serbia sets the stage for Beijing's mask diplomacy, "EUROACTIVE.com”, 2.04.2020, https://www.euractiv.com/section/china/news/serbia-sets-the-stage-for-beijingsmask-diplomacy/ (access 19.10.2021).

39 Brdo Declaration, op.cit. 
further unrealistic dates. The EU should also fulfil its promises and open accession negotiations with North Macedonia and Albania at the soonest possible date, as well as decide on visa liberalisation for the residents of Kosovo. It is vital for the EU to maintain credibility not only in the eyes of the Balkan leaders but also the citizens of the region. The current situation can be described in the following words: "[ $t]$ he EU pretends to offer membership and we pretend to be interested in joining". ${ }^{40}$ Thus, to succeed in this challenge, the EU must cease being passive; otherwise other major players (including China, Turkey, and Russia) will take advantage of the situation. As Dimitar Bechev said, "[i]f accession is no longer a credible prospect, Balkan power players are likely to shun Brussels' demands, look elsewhere for political support and economic rewards, and take the European Union for granted". ${ }^{41}$

\section{References}

Barigazzi J., EU commissioner floats shift on Albania membership talks, "Politico", 07.05.2021, https://www.politico.eu/article/eu-commissionalbania-membership/ (access 2.10.2021).

Brdo Declaration, 6 October 2021, 2021, https://www.consilium.europa. eu/media/52280/brdo-declaration-6-october-2021-en.pdf (access 18.10.2021).

Bunguri E., EU vaccine rollout 'morally and politically unjustified', says Albania PM, 15.01.2021, https://www.euronews.com/2021/01/15/euvaccine-rollout-morally-and-politically-unjustified-says-albania-pm (access 19.10.2021).

Cuckić N., Transparency International: Corruption is on the rise in the Western Balkans, 04.02.2021, https://europeanwesternbalkans.com/2021/02/04/ transparency-international-corruption-is-on-the-rise-in-the-westernbalkans/ (access 10.09.2021).

Dempsey J., Fudy Asks: Has the EU Lost the Western Balkans?, "Carnegie Europe”, 14.10.2021, https://carnegieeurope.eu/strategiceurope/85563 (access 19.10.2021).

Domachowska A., Nowezasady rozszerzenia Unii Europejskiejireakcje państw Batkanów Zachodnich, „Komentarze IEŚ 118”, 14.02.2020, https://ies. lublin.pl/komentarze/nowe-zasady-rozszerzenia-unii-europejskiej-ireakcje-panstw-balkanow-zachodnich/ (access 28.09.2021).

${ }^{40}$ J. Dempsey, Fudy Asks: Has the EU Lost the Western Balkans?, "Carnegie Europe", 14.10.2021, https://carnegieeurope.eu/strategiceurope/85563 (access 19.10.2021).

${ }^{41}$ Ibidem. 
Đorđević N., Montenegro narrowly avoids Chinese debt trap, for now, 09.08.2021, https://emerging-europe.com/news/montenegro-narrowlyavoids-chinese-debt-trap-for-now/ (access 19.10.2021).

EUROACTIVE.com, Serbia sets the stage for Beijing's mask diplomacy, 2.04.2020, https://www.euractiv.com/section/china/news/serbia-setsthe-stage-for-beijings-mask-diplomacy/ (access 19.10.2021).

Euronews, EU commits $€ 9$ billion to Western Balkans but political divisions over enlargement persist, 6.10.2021, https://www.euronews.com/2021/10/06/ eu-commits-9-billion-to-western-balkans-but-political-divisionsover-enlargement-persist (access 18.10.2021).

Euronews.Albania, Bulgaria and North Macedonia clash, overshadowing the European perspective of the Westen Balkans once again, 1.10.2021, https:// euronews.al/en/north-macedonia/2021/10/01/bulgaria-and-northmacedonia-clash-overshadowing-the-european-perspective-of-thewesten-balkans-once-again/ (access 5.10.2021).

European Council, EU-Western Balkans summit, Brdo pri Kranju, Slovenia, 6 October 2021, 2021, https://www.consilium.europa.eu/en/meetings/ international-summit/2021/10/06/ (access 18.10.2021).

Eurostat, Western Balkans-EU - international trade in goods statistics, 2021, https://ec.europa.eu/eurostat/statistics-explained/index. php?title=Western_Balkans-EU_-_international_trade_in_goods_ statistics\&oldid $=526493$ (access 19.10.2021).

Freedom House, Nations in Transit 2021, The Antidemocratic Turn, 2021, https://freedomhouse.org/sites/default/files/2021-04/NIT_2021_ final_042321.pdf (access 20.09.2021).

Gotev G., Funcker tells Balkan states 2025 entry possible for all, 26.02.2018, https://www.euractiv.com/section/enlargement/news/juncker-tellsbalkan-states-2025-entry-possible-for-all/ (access 2.10.2021).

Ivović A., Perception of EU aid amidst the pandemic faces challenges across the Western Balkans, "European Western Balkans", 17.04.2020, https:// europeanwesternbalkans.com/2020/04/17/perception-of-eu-aidamidst-the-pandemic-faces-challenges-across-the-western-balkans/ (access 19.10.2021).

Janković S., Proi korak za izlazak Crne Gore iz duga prema Kini, „Radio Slobodna Evropa", 09.07.2021, https://www.slobodnaevropa.org/a/ crna-gora-kina-kredit-dug/31350750.html (access 19.10.2021).

Juncos A.E., Vaccine Geopolitics and the EU's Ailing Credibility in the Western Balkans, "Carnegie Europe", 08.07.2021, https://carnegieeurope. eu/2021/07/08/vaccine-geopolitics-and-eu-s-ailing-credibility-inwestern-balkans-pub-84900 (access 19.10.2021). 
Komisja Europejska, Liberalizacja przepisów wizowych: Komisja potwierdza, że Kosowo spetnia wszystkie wymagane kryteria, 18.07.2018, https:// ec.europa.eu/commission/presscorner/detail/pl/IP_18_4562 (access 21.09.2021).

Latal S., et al. Western Balkans Awaits EU Summit as Membership Hopes Falter, "Balkan insight", 6.10.2021, https://balkaninsight.com/2021/10/06/ western-balkans-awaits-eu-summit-as-membership-hopes-falter/ (access 18.10.2021).

Parliamentary Assembly, North Macedonia's accession to the EU: 'It is high time to move forward', says Nikola Dimitrov, 30.09.2021, https://pace.coe. int/en/news/8458/north-macedonia-s-accession-to-the-eu-it-is-hightime-to-move-forward-says-nikola-dimitrov (access 5.10.2021).

Pawłowski K., "Dtuga Droga": Macedonia Pótnocna cztonkiem NATO, „Komentarze IEŚ,,nr 172, 17.04.2020, https://ies.lublin.pl/komentarze/ dluga-droga-macedonia-polnocna-czlonkiem-nato/ (access 8.10.2021).

Regional Cooperation Council, Balkan Barometer 2021. Infographics. Pocket Edition, 2021, https://www.rcc.int/download/docs/Balkan_Barometer pocket_web.pdf/d885791a77366a17791270b95a162c16.pdf $\quad$ (access 10.09.2021).

Regional Cooperation Council, Balkan Barometer 2021. Public opinion. Analytical report, 2021, https://www.rcc.int/download/ docs/Balkan_Barometer_Public_opinon_2021v4_compressed.pdf/ fd1f51228c1d9 4 c4f093617 $\overline{\mathrm{da}} 56304048 . \mathrm{pdf}$ (access 28.09.2021).

Schweng Ch., The EU must keep its word to the Western Balkans on the prospect of EU membership, says EESC President, 05.10.2021, https:// www.theparliamentmagazine.eu/news/article/the-eu-must-keep-itsword-to-the-western-balkans-on-the-prospect-of-eu-membershipsays-eesc-president (access 19.10.2021).

Shehadi S., How China is enabling an environmental crisis in the Balkans, "Investment Monitor", 29.01.2021, https://www.investmentmonitor. ai/business-activities/extractive-industries/how-china-is-enabling-anenvironmental-crisis-in-the-balkans (access 12.10.2021).

Siebold S., Sekularac I., Emmott R., EU restates Balkan membership guarantee but won't say for when, 6.10.2021, https://www.reuters.com/ world/europe/despite-french-push-eu-leaders-divided-over-commondefence-strategy-2021-10-06/ (access 18.10.2021).

Simić J., Serbia turns to China due to 'lack of EU solidarity' on coronavirus, "EUROACTIVE.com", 18.03.2020, https://www.euractiv.com/section/ china/news/serbia-turns-to-china-due-to-lack-of-eu-solidarity-oncoronavirus/ (access 19.10.2021). 
Stanicek B., Bośnia i Hercegowina: trudna droga do cztonkostwa w UE, Biuro Analiz Parlamentu Europejskiego, czerwiec, 2021.

Szpala M., Seroka M., Butgarska blokada negocjacji akcesyjnych z Macedonia Pótnocna, „Analizy OSW”, 14.12.2020, https://www.osw.waw.pl/ pl/publikacje/analizy/2020-12-14/bulgarska-blokada-negocjacjiakcesyjnych-z-macedonia-polnocna (access 2.10.2021).

The European Commission, 2021 Enlargement package: European Commission assesses and sets out reform priorities for the Western Balkans and Turkey, 2021, https://ec.europa.eu/commission/presscorner/detail/ en/IP_21_5275 (access 23.10.2021).

The European Parliament, The Western Balkans, 2021, https://www. europarl.europa.eu/factsheets/en/sheet/168/the-western-balkans (access 29.09.2021).

von der Burchard H., Barigazzi J., Gray A., Brussels puts French accent on EU enlargement, "Politico", 4.02.2020, https://www.politico.eu/article/ brussels-tries-to-give-eu-european-union-enlargement-a-frenchaccent-north-macedonia-albania-emmanuel-macron-angela-merkel/ (access 26.09.2021).

Wysocka K., Chiny siegaja po Batkany Zachodnie. Unia Europejska powinna sie niepokoić?, „EUROACTIVE.pl”, 11.04.2021, https://www.euractiv. pl/section/polityka-zagraniczna-ue/news/chiny-balkany-ue-uniaeuropejska-serbia-czarnogora-kosowo-albania-wspolpraca-politykazagraniczna-pekin-ekspansja-chinczycy/ (access 18.10.2021). 